\title{
Working with Startups? These are the Three Things You Ought to Know about Startup Teams Anna Brattström
}

\author{
"Talent wins games, but teamwork and intelligence win championships." \\ Michael Jordan \\ Basketball player
}

\begin{abstract}
While much has been written about how startups work to develop their product, this paper focuses instead on how to manage the startup team. Based on a systematic review of current research, I present actionable insights about startup team characteristics; who they are, how they work, and how they stay together. I explain how these characteristics imply both opportunities and threats for the viability of the team and discuss how startup teams can be managed to increase the likelihood of their survival and growth. Given that the majority of startup failures are attributed to the team, not to the product, these insights are valuable both to aspiring entrepreneurs and to their external stakeholders.
\end{abstract}

\section{Introduction}

In the past decade, we have witnessed a surge of interest in how to manage startup companies. Popular methods have had a fundamental impact on new ventures across the world (for example, Ries, 2011; Blank, 2013), describing how to develop minimum viable products, how to find product-market fit, and how to pivot a business. Interestingly, however, the core reason for why many startups fail is not because of problems in their business; it is rather because of problems in their team. Among venture capitalists, this is well known, and across different surveys (Gorman \& Sahlman, 1989; Kaplan \& Strömberg, 2004), venture capitalists attribute between $60-65 \%$ of failures to problems within the startup team. Yet, there is a noticeable lack of practical advice on how to successfully manage a startup team.

In academic research, scholars have recently begun to pay more attention to the startup team (Klotz et al., 2014; Lazar et al., 2019). Results, however, are mainly directed towards an academic audience. They are divided into fairly narrow subdisciplines, such as sociology (Ruef, 2010); strategy (Eisenhardt, 2013) or social psychology (Breugst \& Shepherd, 2017), and as such, typically not accessible to practitioners. This leaves entrepreneurs, as well as the investors, partners and incubators that work with them, lacking researchbased insights into startup teams and how they function. Given how much we already know about how to manage startups, it is time we also pay attention to the fundamental issue of how to manage collaborations with and within the new venture team.

Addressing this need for knowledge, I present in this paper actionable insights about startup teams; who they are, how they work, and how they stay together. My model is based on a thorough review of state-of-the-art research about startups. I curate this research into stylized facts about startup teams, concluding with an actionable framework to help practical assessments of startup teams' viability. My core purpose is to offer practitioners research-based knowledge about how to organize and manage startup teams, with an aim of complementing the abundance of literature that focuses on how to organize and manage new ventures.

\section{Literature Background}

The majority of entrepreneurship research focuses on individual entrepreneurs, seeking to understand the personalities, abilities, and motivations that make them successful (Davidsson \& Honig, 2003; Wiklund et al., 2003; McKelvie et al., 2018). Yet, most startups are founded and managed by teams, not by entrepreneurs who operate in solo (Ruef, 2010). Knowledge-intensive startups that pursue innovation and growth especially are more often founded by teams than by single entrepreneurs (Hellerstedt, 2009; Steffens et al., 2012). Understanding what makes these teams come together, work together and stay together is an important, but currently under evaluated, aspect of entrepreneurship. 


\section{Working with Startups? These are the Three Things You Ought to Know about Startup Teams Anna Brattström}

For the purpose of this paper, I define a startup team broadly as "two or more individuals who commit to each other to create a new firm" (Brattström et al., 2019). Startups come in many forms. Most are smallscale businesses, never intended to become more than a source of income for the founding team. In this paper, however, my core focus is on innovative, knowledge-intensive startups formed with an intention to grow and perhaps scale, hereafter referred to as startup teams.

To date, systematic evidence on the operation of startup teams has been generated from scholars in three different academic sub-disciplines. The first is deeply rooted in sociology (Aldrich \& Kim, 2007; Ruef et al., 2009; Kim et al., 2013). Research in this discipline provides important insights into how startup team members come together, such as how their relationships, status, or social networks influence how members team up with each other. This research is fundamental for understanding the composition of startup teams and how such composition influences team operations over time. The second tradition finds its roots in strategy research (Beckman \& Burton, 2008; Eisenhardt, 2013; Eberhart et al., 2017). An important focus of scholars in this tradition has been to investigate the economic context in which a startup team operates. As a result, we have gained important insights into how teams deal with uncertainty and velocity, using limited resources. The third research tradition takes standpoint in social psychology (Breugst et al., 2015; Breugst \& Shepherd, 2017; Cardon et al., 2017). Inspired by team research more broadly (Marks et al., 2001; Mathieu et al., 2017), this research has generated insights into how the dynamic interactions among team members influence startup team functioning over time.

In this paper, I integrate these academic insights into three stylized facts about startup teams and how they operate. Thus, I do not claim to provide a full account of all research in the field. For this, I refer to the excellent recent reviews of Klotz et al. (2014), Jin et al. (2017), and Lazar et al. (2019). Instead, my core purpose here is to provide curated insights, accessible to practitioners.

\section{How I Identified Relevant Research}

To ensure an accurate and comprehensive reading, I engaged in a structured review of research on startup teams. I began by searching the Web of Science database for articles published under the topic of new venture teams in the last 22 years (from January 1st 1997 until June 3rd 2019). I searched for articles covering topics with the combinations of the words "team(s)" or "group(s)" in together with: start-up, entrepreneurial, new venture, founding, and nascent. This generated a list of 225 papers. From this list, I selected journals that had published two or more papers on the topic. This restricted my list to 166 papers. Thereafter, I read each abstract in order to identify papers which specifically addressed the role of teams for new venture performance. In addition, I also benefited from scholarly books in the field, in particular the works of Ruef (2010) and Wasserman (2008).

The scope of my review differs from Klotz et al. (2014) in two fundamental ways. First, I included conceptual papers, in addition to only empirical papers. Second, I included the term "group", in addition to the term "team". Third, instead of restricting my analysis to a particular set of journals prior to the search, I first conducted a broad search in Web of Science.

\section{Three Stylized Facts about Startup Teams}

In the following, I integrate current research into three stylized facts about startup teams; simplified generalizations that help to summarize what we currently know. As stylized facts, the insights presented in this paper are not necessarily true to all startup teams, in all places, and at all times. Moreover, it is also important to keep in mind that research on startup teams is an emergent field, and that much remains to be understood about this phenomenon.

\section{Stylized fact no. 1: they are birds of similar feathers}

Most startup teams are homogenous, meaning that team members share similar attributes, skills, and characteristics. This is well established across different samples of startups. In the US, for instance, researchers found that almost half of all startup teams that are formed are all-male or all-female teams (Ruef et al, 2003; Ruef et al., 2009). Moreover, ethnically homogenous teams are considerably more common than mixed teams (Ruef et al., 2009; Ruef, 2010). In a US study, it was even found that almost $30 \%$ of startup teams are composed of individuals who share the same occupational experiences (Ruef et al., 2009). We also see homophily being put to practice in several well-known startup teams. Snapchat, for example, was founded by three young men, all graduates of Stanford University, and Facebook was formed among a group of roommates at Harvard University. 


\section{Working with Startups? These are the Three Things You Ought to Know about Startup Teams Anna Brattström}

\section{Drivers of homogeneity: social networks and in-group bias}

At first glance, such homogeneity might seem surprising. Given their ambitions to come up with new innovation, explore novel business opportunities and overturn existing markets (McKelvie et al., 2017; McKelvie et al., 2018), one might expect entrepreneurs to team up in heterogenous teams in order to spur creativity and innovation. Taking a closer look into how startup teams are formed, however, the homogeneity of teams becomes more understandable. After all, homophily, i.e. the tendency of human beings to seek similar others, is deeply rooted in human nature (McPherson et al., 2001).

Two strong forces drive this tendency for homogeneity. The first is homogeneity of the social network in which team members are recruited. When it is time to form a new venture, entrepreneurs look for team mates in their social networks. Studying US data, Ruef (2010) for instance found that $14-17 \%$ of all startup teams are founded among former co-workers, and $19-21 \%$ are formed among friends or aquaintances. The second force driving homogeneity is startup teams' in-group bias. As human beings, we simply seem to be more inclined to positively evaluate, trust, and collaborate with similar others (Tajfel, 1978; Tajfel \& Turner, 1986). Such trust, in turn, is an important performance driver in teams (Brattström et al., 2012; Brattström \& Richtnér, 2014). When forming a group, we therefore tend to flock with those that are similar to ourselves. This is well established across different types of relationships, from marriages to friendships (McPherson et al., 2001). Interestingly, teams in established organizations are important exceptions to this principle. Different from marriages or friendships, teams in established organizations are deliberately designed. For such teams, members are usually assigned rather than self-selected. Startup teams, however, emerge because team members chose to work together. When making that choice, it seems that the comfort of similarity exerts a larger influence than the potential advantage of seeking out someone different with the same or better skillset.

\section{Implications of homogeneity: efficiency at the cost of blind spots}

On the bright side, homogeneity often makes the startup team function smoothly. In general, homogenous teams tend to perform better than heterogenous ones (Murnighan \& Conlon, 1991). For example, homogenous teams are better at solving complex problems (Woolley et al., 2010), have lower turnover, and also a higher degree of cohesion (O'Reilly III et al., 1989), which in turn makes them better able to productively manage conflict (Ensley et al., 2002). By and large, homogenous teams are efficient and agile, which are important characteristics of successful startups.

On the darker side, homogenous teams can be subject to cognitive and social blind spots (Steffens et al., 2012). Cognitively, heterogenous teams bring together different skills, resources, competences, perspectives, and social network contacts. This allows team members to draw on a wider breadth of perspectives (Van Knippenberg et al., 2004; Van Knippenberg et al., 2015) and contacts (Milanov \& Fernhaber, 2009). In the volatile and dynamic context that characterize startups, this gives heterogenous teams an important advantage over homogenous ones.

Socially, teams that are composed of friends may not have the type of formal authority that sometimes is required to establish leadership and work relationships (Reagans et al., 2004). This can make roles and relationships blurred within the team, ultimately hampering startup performance (Jung et al., 2017).

\section{Dealing with homogeneity: towards more reflective decision making}

An important thing to realize about social network constraints and in-group bias is that they unconsciously influence choice of startup team members. Therefore, when forming a team, it is important to explicitly reflect on what grounds team members are chosen. Is it because they are best suited or is it because they happen to be close and available? One might also consider explicit ways to mitigate the disadvantages with overly homogenous teams. For example, if a team is homogenous, it can be important to bring in external stakeholders, whether as board members, consultants or coaches, who bring a wider set of perspectives and network to the team (Vandenbroucke et al., 2016).

\section{Stylized fact no. 2: Their only constant is change}

\section{Drivers of change: market, technological and financial uncertainty}

Managing a startup is about managing change. The process, however, is rarely smooth. Instead, it is described as a process of "creative revision" (Grimes, 2018), meaning that the startup team needs to constantly revisit and revise taken-for granted assumptions about their product and their customer. In a study of high-tech firms, Shane (2008) found that almost half $(49.6 \%)$ of all startups change their initial 


\section{Working with Startups? These are the Three Things You Ought to Know about Startup Teams Anna Brattström}

business idea. YouTube is a great example. Before YouTube pivoted into what it is known for today, this video-streaming service was launched as a dating-site, where users could upload videos in search for potential partners.

A strained financial situation further adds a need for change. Most startup teams, especially those that are engaged in costly innovations, face a constant shortage of cash. As a result, entrepreneurs may need to revise their ambitions and work practices over time: beggars can seldom be choosers. Sometimes, change is driven by the individual members of the team. Starting and growing a firm is often a long-term process, unfolding over several years. During this time, aspirations and motivations of individual entrepreneurs can change, as does family situation, health conditions or the availability of outside options. When this happens, it has implications for the aspirations and activities of other team members.

Finally, as the company develops and matures, new skills are needed. New members enter and old ones exit, leading to change in team composition, boundaries, and size. Even for those individuals who stay in the team, roles and relationships may change over time. In the beginning, team members may collectively take on a wide range of tasks, from product development to sales. Over time comes the need for role specialization, demanding some individuals to step up while others might need to take a step back.

\section{Implications of change: need to adapt team structures}

In short, startup teams deal more with change than stability. Surprisingly, however, many startups are rigid in the sense that members struggle to adapt to roles, relationships, and equity splits over time. Across several studies, researchers have found that the set of initial conditions, such as partnerships or resources, have a long-lasting impact on the future of the startup (Schoonhoven et al., 1990; Milanov \& Fernhaber, 2009). For example, the set of values that represents the initial founding team typically has a strong imprinting effect on the new venture, guiding the future norms and values of the emergent organization (Baron et al., 1999). Along similar lines, studies have shown that the initial divisions of roles and relationships in a startup typically prevail over time. Even as conditions change for the startup, many startup teams find it difficult to adapt their organizational structure accordingly (Beckman \& Burton, 2008).

One explanation is that change is challenging for teams. Divisions of roles, responsibilities, and rewards are closely related to perceptions of fairness; thus changing them can easily provoke conflict (Breugst et al., 2015). In the early stage of a startup's life, it may seem fair to make an equal split: each founder gets the same amount of equity. Over time, however, the issue of equity splitting can be more complicated. One member might find herself working harder than the others; another member might realize that he contributes more; a third member might be added to the team, requiring original founders to renegotiate equity. Such renegotiations easily turn nasty (Breugst et al., 2015; Breugst \& Shepherd, 2017; Jung et al., 2017; Brattström, 2018). In one study, for example, Breugst et al. (2015) followed eight startup teams over six months and found that perceived justice in how equity was split had profound implications for team outcomes. In teams where members thought that equity distribution was just, a positive spiral emerged, drawing team members closer to one another. However, when these teams faced external threats, such as being pressured by an investor or questioned by board members, they easily drifted from a positive spiral into a negative one. Even in those cases where the initial equity distribution was considered fair, external threats made team members doubt each other, leading to conflict and turnover within the team.

\section{Dealing with change: incorporate dynamics into the structure of the venture}

Whether working within or with a startup team, it is important nowadays to incorporate change into work practices. One example is to use dynamic equity splits (Wasserman, 2008). In such agreements, members of the startup team pre-define milestones, phases in the startup life, and the roles and relationships within each phase. These definitions are subsequently used to structure discussions and renegotiations about equity splits within the team. As Wasserman (2008) notes, an important implication of such dynamic agreements is that they make both the tangible and the intangible factors salient for the team.

Along similar lines, startup teams might benefit from scheduling regular reviews of roles and relationships within their team. One option, advocated by Beckman and Burton (2008), is to create "organizational placeholders" already at the inception of the firm. For example, to make explicit early on that at some point, someone in the team will need to assume the role of the CEO, CFO, or CTO, even though it can remain an open question about when, how, and to whom this happens. Another option is to involve external stakeholders, 


\section{Working with Startups? These are the Three Things You Ought to Know about Startup Teams Anna Brattström}

mentors or board members, in regularly revisiting team members' (implicit) assumptions about roles and relationships in the team.

Independent on which option that is chosen, discussing roles, rewards and relationships over time is an important sensemaking exercise. As human beings, we tend to count what can be easily measured, even though we know that not all that can be measured counts (Brattström et al., 2018). To avoid falling apart in times of change, startup teams need to turn difficult though necessary discussions into qualitative and collective sensemaking exercises, rather than making them numbers-games where different individuals fight for a larger share of the pie.

\section{Stylized fact no. 3: emotion is the glue that keeps them together}

Entrepreneurship requires persistence (Markman et al., 2005; Wu et al., 2007). This is true for entrepreneurs in general; entrepreneurs who stubbornly pursue their goals (Timmons \& Spinelli, 1994) believe in their own abilities (Shane et al., 2003), and have passion for their company (Cardon et al., 2017), have a higher likelihood of succeeding. FedEx, for example, is a company that was about to go bankrupt, but survived merely due to the founders' persistence. During the first years of operations, FedEx lost millions of dollars every year, leading several investors to suggest that its original founder, Frederick Smith, should step down from operations. Smith, however, remained persistent and eventually managed to turn FedEx into a great success. In a startup team, persistence is even more complicated than for a solo-operating entrepreneur such as Smith. In addition to being persistent about their new venture, entrepreneurs must also be persistent in terms of their team. When the going gets rough, it is easy to turn failures into a blame game among team members. For a team to work together, however, members must persistently keep together.

\section{Factors that strain team commitment}

There are many issues that strain commitment in new venture teams. One example is time. We know from team research that commitment is easier in the early stages of a team's development (Tuckman, 1965). Known as the "forming stage", members tend to be careful with each other as they test and develop norms around appropriate behavior. Over time, however, teams in general often undergo a "storming phase", when the challenges of task demands, and interpersonal differences start to surface (Tuckman,
1965). This can lead to conflicts, stress, and quarrels that challenge team members' persistence.

Another issue that can strain commitment is stress. Organizing a startup is a process fraught with challenges and setbacks. Product development timelines are often delayed, sales can be lower than expected, and investors pose difficult demands on the team. Such setbacks cause stress that challenges team commitment. Busenitz, Moesel, Fiet, and Barney (1997), for instance, found that new venture team members who felt unfairly treated by investors were more likely to leave their teams.

\section{Implications of team exits: positive and negative}

To some extent, team member turnover is necessary for startups. As the venture matures, the team requires novel competences, leading to new members entering the team, whereas other members leave (Ucbasaran et al., 2003). In many situations, however, team members exits can constitute nasty divorces. They are foregone by unproductive conflict and leave behind wounds that need to heal. This latter type of team divorce is one that needs to be prevented because it distracts the team from constructive problem solving, consumes attention and effort, and decreases the likelihood of a startup's success (Busenitz et al., 2004).

\section{Preventing dysfunctional team exits: nurture the emotions that keeps the team together}

In the context of established organizations, teams can be held together by strong managers who force persistence upon the team, by contracts that makes persistence legally binding, or by salaries that are paid out as compensation for loyalty. Among startup founders, however, there is no manager or contract to force members to stay together, and salaries are often both uncertain and distant. Instead, emotions, such as passion, attachment, joy, and energy constitute an important glue that keeps the team together (Cardon et al., 2017; Brattström, 2018). Shared positive emotions, for example, enable team members to learn from each other (Klimoski \& Mohammed, 1994) and improve their abilities to work together (Rhee, 2006). In a similar vein, a feeling of shared identity is also important, as it tends to increase information exchange and promote cooperation in teams (Chatman \& Flynn, 2001). By and large, building emotional attachment to and identification with an organization and team enhance the likelihood that startup team members persist (Mathieu \& Zajac, 1990; Meyer et al., 2002).

Emotions play an important role also for how team members behave (Baron, 2008; Cardon et al., 2012). 


\section{Working with Startups? These are the Three Things You Ought to Know about Startup Teams Anna Brattström}

Welpe et al., (2012), for instance, demonstrated that entrepreneurs who feel vigorous are more likely to engage in proactive behavior, whereas entrepreneurs who feel satisfied are more likely to engage in reactive behavior. In an experimental study Hahn et al., (2012) also concluded that fear tends to reduce entrepreneurs' tendencies to explore novel opportunities, whereas joy and anger tend to increase exploration. In all cases, this seems to make emotions a matter of priority.

\section{A Framework to Guide Assessment of a Startup Team}

In sum, there are three things one ought to know about startup teams. First, that they are often homogenous groups. This makes them agile but sometimes subject to cognitive and social blind spots. Second, that they work under conditions of constant change, although they often find it surprisingly difficult to adapt roles, relationships, and rewards over time. Third, that they are entirely dependent on members' voluntary commitment, but struggle to keep together in difficult times.

Knowing these things is important, because it helps to better understand how startup teams function. This is important for entrepreneurs themselves, who look to form the best team possible and to develop that team into its full potential. It's equally important for external stakeholders, whether venture capitalists, potential alliance partners, or incubator coaches. If an investor is about to spend time and money in such an uncertain endeavor as a startup, he or she ought to be able to identify the strengths and weaknesses of the team that is supposed to make it happen.

In Figure 1, I present a guiding framework to help make such assessments. The framework is intended to be used both by aspiring entrepreneurs, by teams that are already in operation, as well as external stakeholders, such as investors. For an aspiring entrepreneur, the framework can help to develop a better understanding of what would be a potential "dream team". For an existing team, the framework can be used as a sensemaking device, to encourage discussions about strengths, weaknesses, and possible areas of improvement. For an investor, the framework provides guidance to enable a qualitative assessment of potential investments. Afterall, it is the team, just as much as the idea they pursue, that determines startup success (Gorman \& Sahlman, 1989; Kaplan \& Strömberg, 2004).

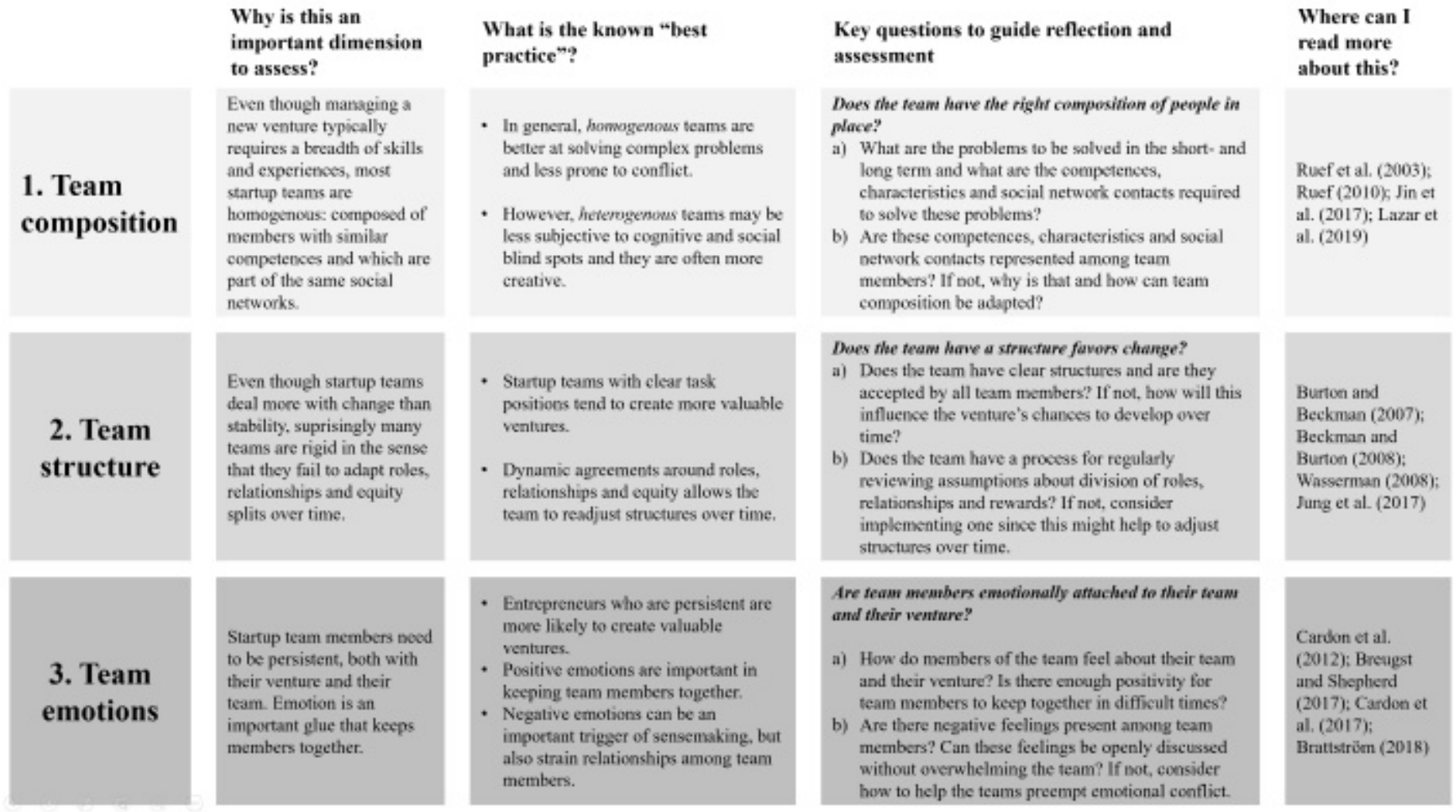

Figure 1. A framework to guide team assessment in three core dimensions 


\section{Working with Startups? These are the Three Things You Ought to Know about Startup Teams Anna Brattström}

In line with the stylized facts I have presented above, the framework breaks down team assessments into three core dimensions represented in rows. 1. Team composition, to allow assessment about who the startup team is. 2. Team structure, to allow assessment of how the team works. 3. Team emotion, to allow insights about how members stay together. For each dimension, I first explain why this particular issue is an important area of reflection and assessment. In the second column, I briefly summarize the known "best practice". In the third column, I provide questions to help guide assessment about a startup team. These questions are qualitative in nature and as such, they are designed to encourage reflection, rather than a quantitative "scoring" of a team. The final column provides some reference pointers about where to turn for further depth and insights about these important matters.

When assessing a startup team, it is important to keep in mind that team composition, team structure, and team emotions are not isolated but interrelated. Team composition, for instance, influences emotionality; a team of friends might have a surplus of positive emotions among them, while a team of strangers may be more emotionally detached to each other. In a similar way, team structure might influence how the team is composed: a team with specific place-holder positions (for example, CEO, CTO, and so forth) might be encouraged to search for team members that encompass the capabilities to uphold such positions, whereas a team that does not have designed placeholders might be less systematic in their search for new team members (Beckman \& Burton, 2008). Because the three dimensions are interrelated, Figure 1 does not imply that assessment should be made in any particular order. For some teams, it can make sense to start with a reflection on emotionality, for others, it can make sense to start with an analysis of team composition.

Neither does Figure 1 give greater weight to one dimension over others. Instead, the three dimensions should be seen as complementary. There is no such thing as a "perfect team" and rather than striving for perfection, it can make sense to consider how strength in one dimension can compensate for weaknesses in others. For example, a team that is weak in its composition may compensate in persistence, commitment, and positivity. A team in which there is a lot of affective conflict might consider handling it by making changes in the team's structure.
To conclude, it is extremely difficult to predict the performance of a startup (Shepherd et al., 2018). Similarly, it is impossible to single out any one particular factor that explains the performance of a team (Mathieu et al., 2017). In both startups and teams, success is dependent on a myriad of different factors, including luck, and there is more than one road leading to success and failure (Katz \& Kahn, 1978). On the other hand, what can be done is to make an overall assessment of a startup team's viability. This does not guarantee success, but rather decreases the likelihood of failure.

As illustrated in Figure 1, I suggest that such sensemaking should be informed about the issues that typically characterize startup teams. This involves insights for what viable teams need, and should be grounded in solid research. After all, given that the team is such an important aspect of successful entrepreneurship, it is time we pay teams their due attention.

\section{Acknowledgements}

The author gratefully acknowledges financial support from the Ragnar Söderberg Foundation 


\section{Working with Startups? These are the Three Things You Ought to Know about Startup Teams Anna Brattström}

\section{References}

Aldrich, H. E., \& Kim, P. H. 2007. Small Worlds, Infinite Possibilities? How Social Networks Affect Entrepreneurial Team Formation and Search. Strategic Entrepreneurship Journal, 1(1-2): 147-165.

Baron, J. N., Hannan, M. T., \& Burton, M. D. 1999. Building the Iron Cage: Determinants of Managerial Intensity in the Early Years of Organizations. American Sociological Review: 527-547.

Baron, R. A. 2008. The Role of Affect in the Entrepreneurial Process. Academy of Management Review, 33(2): 328-340.

Beckman, C. M., \& Burton, M. D. 2008). Founding the Future: Path Dependence in the Evolution of Top Management Teams from Founding to IPO. Organization Science, 19(1): 3-24.

Blank, S. 2013. Why the Lean Start-up Changes Everything. Harvard Business Review, 91(5): 63-72.

Brattström, A. 2018. Voice and Punctuation: A Process Model of Conflict Enactment in New Venture Teams. Academy of Management Best Paper Proceedings, 2018(1), 16935.

Brattström, A., Delmar, F., Johnson, A., \& Wennberg, K. 2019. A Longitudinal Project of New Venture Teamwork and Outcomes. In B. Gartner \& B. Teague (Eds.), Handbook on Entrepreneurial Behavior, Practice and Process: Edward Elgar.

Brattström, A., Frishammar, J., Richtnér, A., \& Pflueger, D. 2018. Can Innovation Be Measured? A Framework of How Measurement of Innovation Engages Attention in Firms. Journal of Engineering and Technology Management.

Brattström, A., Löfsten, H., \& Richtnér, A. 2012. Creativity, Trust and Systematic Processes in Product Development. Research Policy, 41(4): 743-755.

Brattström, A., \& Richtnér, A. 2014. Good Cop - Bad Cop: Trust, Control and the Lure of Integration. Journal of Product Innovation Management, 31(3): 584-598.

Breugst, N., Patzelt, H., \& Rathgeber, P. 2015. How Should We Divide the Pie? Equity Distribution and Its Impact on Entrepreneurial Teams. Journal of Business Venturing, 30(1): 66-94.

Breugst, N., \& Shepherd, D. A. 2017. If You Fight with Me, I'll Get Mad! A Social Model of Entrepreneurial Affect. Entrepreneurship Theory and Practice, 41(3): 379-418.

Busenitz, L. W., Fiet, J. O., \& Moesel, D. D. 2004. Reconsidering the Venture Capitalists'“Value Added" Proposition: An Interorganizational Learning Perspective. Journal of Business Venturing, 19(6): 787807.

Busenitz, L. W., Moesel, D. D., Fiet, J. O., \& Barney, J. B. 1997. The Framing of Perceptions of Fairness in the Relationship between Venture Capitalists and New Venture Teams. Entrepreneurship Theory and Practice, 21(3): 5-22.
Cardon, M. S., Foo, M. D., Shepherd, D., \& Wiklund, J. 2012. Exploring the Heart: Entrepreneurial Emotion Is a Hot Topic. Entrepreneurship Theory and Practice, 36(1): 1-10.

Cardon, M. S., Post, C., \& Forster, W. R. 2017. Team Entrepreneurial Passion: Its Emergence and Influence in New Venture Teams. Academy of Management Review, 42(2): 283-305.

Chatman, J. A., \& Flynn, F. J. 2001. The Influence of Demographic Heterogeneity on the Emergence and Consequences of Cooperative Norms in Work Teams. Academy of Management Journal, 44(5): 956-974.

Davidsson, P., \& Honig, B. 2003. The Role of Social and Human Capital among Nascent Entrepreneurs. Journal of Business Venturing, 18(3): 301-331.

Eberhart, R. N., Eesley, C. E., \& Eisenhardt, K. M. 2017. Failure Is an Option: Institutional Change, Entrepreneurial Risk, and New Firm Growth. Organization Science, 28(1): 93-112.

Eisenhardt, K. M. 2013. Top Management Teams and the Performance of Entrepreneurial Firms. Small Business Economics, 40(4): 805-816.

Ensley, M. D., Pearson, A. W., \& Amason, A. C. 2002. Understanding the Dynamics of New Venture Top Management Teams: Cohesion, Conflict, and New Venture Performance. Journal of Business Venturing, 17(4): 365-386.

Gorman, M., \& Sahlman, W. A. 1989. What Do Venture Capitalists Do? Journal of Business Venturing, 4(4): 231-248.

Grimes, M. G. 2018. The Pivot: How Founders Respond to Feedback through Idea and Identity Work. Academy of Management Journal, 61(5): 1692-1717.

Hahn, V. C., Frese, M., Binnewies, C., \& Schmitt, A. 2012. Happy and Proactive? The Role of Hedonic and Eudaimonic Well-Being in Business Owners' Personal Initiative. Entrepreneurship Theory and Practice, 36(1): 97-114.

Hellerstedt, K. 2009. The Composition of New Venture Teams: Its Dynamics and Consequences. Jönköping International Business School.

Jin, L. L., Madison, K., Kraiczy, N. D., Kellermanns, F. W., Crook, T. R., \& Xi, J. 2017. Entrepreneurial Team Composition Characteristics and New Venture Performance: A Meta-Analysis. Entrepreneurship Theory and Practice, 41(5): 743-771.

Jung, H. J., Vissa, B., \& Pich, M. 2017. How Do Entrepreneurial Founding Teams Allocate Task Positions? Academy of Management Journal, 60(1): 264-294.

Kaplan, S. N., \& Strömberg, P. E. 2004. Characteristics, Contracts, and Actions: Evidence from Venture Capitalist Analyses. The Journal of Finance, 59(5): 2177-2210.

Katz, D., \& Kahn, R. L. 1978. The Social Psychology of Organizations (Vol. 2): Wiley New York. 


\section{Working with Startups? These are the Three Things You Ought to Know about Startup Teams Anna Brattström}

Kim, P. H., Longest, K. C., \& Aldrich, H. E. 2013. Can You Lend Me a Hand? Task-Role Alignment of Social Support for Aspiring Business Owners. Work and Occupations, 40(3): 213-249.

Klimoski, R., \& Mohammed, S. 1994. Team Mental Model: Construct or Metaphor? Journal of Management, 20(2): 403-437.

Klotz, A. C., Hmieleski, K. M., Bradley, B. H., \& Busenitz, L. W. 2014. New Venture Teams a Review of the Literature and Roadmap for Future Research. Journal of Management, 40(1): 226-255.

Lazar, M., Miron-Spektor, E., Agarwal, R., Erez, M., Goldfarb, B., \& Chen, G. 2019. Entrepreneurial Team Formation. Academy of Management Annals(ja).

Markman, G. D., Baron, R. A., \& Balkin, D. B. 2005. Are Perseverance and Self Efficacy Costless? Assessing Entrepreneurs' Regretful Thinking. Journal of Organizational Behavior: The International Journal of Industrial, Occupational and Organizational Psychology and Behavior, 26(1): 1-19.

Marks, M. A., Mathieu, J. E., \& Zaccaro, S. J. 2001. A Temporally Based Framework and Taxonomy of Team Processes. Academy of Management Review, 26(3): 356-376.

Mathieu, J. E., Hollenbeck, J. R., van Knippenberg, D., \& Ilgen, D. R. 2017. A Century of Work Teams in the Journal of Applied Psychology. Journal of Applied Psychology, 102(3): 452.

Mathieu, J. E., \& Zajac, D. M. 1990. A Review and MetaAnalysis of the Antecedents, Correlates, and Consequences of Organizational Commitment. Psychological bulletin, 108(2): 171.

McKelvie, A., Brattström, A., \& Wennberg, K. 2017. How Young Firms Achieve Growth: Reconciling the Roles of Growth Motivation and Innovative Activities. Small Business Economics, 49(2): 273-293.

McKelvie, A., Wiklund, J., \& Brattström, A. 2018. Externally Acquired or Internally Generated? Knowledge Development and Perceived Environmental Dynamism in New Venture Innovation. Entrepreneurship Theory and Practice, 42(1): 24-46.

McPherson, M., Smith-Lovin, L., \& Cook, J. M. 2001. Birds of a Feather: Homophily in Social Networks. Annual Review of Sociology, 27(1): 415-444.

Meyer, J. P., Stanley, D. J., Herscovitch, L., \& Topolnytsky, L. 2002. Affective, Continuance, and Normative Commitment to the Organization: A MetaAnalysis of Antecedents, Correlates, and Consequences. Journal of Vocational Behavior, 61(1): 20-52.

Milanov, H., \& Fernhaber, S. A. 2009. The Impact of Early Imprinting on the Evolution of New Venture Networks. Journal of Business Venturing, 24(1): 46-61.

Murnighan, J. K., \& Conlon, D. E. 1991. The Dynamics of Intense Work Groups: A Study of British String Quartets. Administrative Science Quarterly: 165-186.
O'Reilly III, C. A., Caldwell, D. F., \& Barnett, W. P. 1989. Work Group Demography, Social Integration, and Turnover. Administrative Science Quarterly: 21-37.

Reagans, R., Zuckerman, E., \& McEvily, B. 2004. How to Make the Team: Social Networks vs. Demography as Criteria for Designing Effective Teams. Administrative Science Quarterly, 49(1): 101-133.

Rhee, S.-Y. 2006. Shared Emotions and Group Effectiveness: The Role of Broadening-and-Building Interactions. Paper presented at the Academy of Management Proceedings.

Ries, E. 2011. The Lean Startup: How Today's Entrepreneurs Use Continuous Innovation to Create Radically Successful Businesses. Crown Books.

Ruef, M. 2010. The Entrepreneurial Group: Social Identities, Relations, and Collective Action. Princeton University Press.

Ruef, M., Aldrich, H. E., \& Carter, N. M. 2003. The Structure of Founding Teams: Homophily, Strong Ties, and Isolation among Us Entrepreneurs. American Sociological Review: 195-222.

Ruef, M., Bonikowski, B., \& Aldrich, H. E. 2009. Business Owner Demography, Human Capital, and Social Networks New Firm Creation in the United States, Springer: 95-114.

Schoonhoven, C. B., Eisenhardt, K. M., \& Lyman, K. 1990. Speeding Products to Market: Waiting Time to First Product Introduction in New Firms. Administrative Science Quarterly, 35(1): 177-207.

Shane, S., Locke, E. A., \& Collins, C. J. 2003. Entrepreneurial Motivation. Human Resource Management Review, 13(2): 257-279.

Shane, S. A. 2008. The Illusions of Entrepreneurship: The Costly Myths That Entrepreneurs, Investors, and Policy Makers Live By. Yale University Press.

Shepherd, D. A., Wennberg, K., Suddaby, R., \& Wiklund, J. 2018. What Are We Explaining? A Review and Agenda on Initiating, Engaging, Performing, and Contextualizing Entrepreneurship. Journal of Management, 0149206318799443.

Steffens, P., Terjesen, S., \& Davidsson, P. 2012. Birds of a Feather Get Lost Together: New Venture Team Composition and Performance. Small Business Economics, 39(3): 727-743.

Tajfel, H., \& Turner, J. C. 1986. The Social Identity Theory of Intergroup Behavior. In S. Worchel \& W. Austin (Eds.), Psychology of Intergroup Relations. Chicago: Nelson-Hall: 7-24.

Tajfel, H. E. 1978. Differentiation between Social Groups: Studies in the Social Psychology of Intergroup Relations. Academic Press.

Timmons, J. A., \& Spinelli, S. 1994. New Venture Creation: Entrepreneurship for the 21st Century (Vol. 4): Irwin Burr Ridge, IL.

Tuckman, B. W. 1965. Developmental Sequence in Small Groups. Psychological bulletin, 63(6): 384. 


\section{Working with Startups? These are the Three Things You Ought to Know about Startup Teams Anna Brattström}

Ucbasaran, D., Lockett, A., Wright, M., \& Westhead, P. 2003. Entrepreneurial Founder Teams: Factors Associated with Member Entry and Exit. Entrepreneurship Theory and Practice, 28(2): 107-127.

Van Knippenberg, D., Dahlander, L., Haas, M. R., \& George, G. 2015. Information, Attention, and Decision Making. Academy of Management Journal, 58(3): 649-657.

Van Knippenberg, D., De Dreu, C. K., \& Homan, A. C. 2004. Work Group Diversity and Group Performance: An Integrative Model and Research Agenda. Journal of Applied Psychology, 89(6): 1008.

Vandenbroucke, E., Knockaert, M., \& Ucbasaran, D. 2016. Outside Board Human Capital and Early Stage High-Tech Firm Performance. Entrepreneurship Theory and Practice, 40(4): 759-779.

Wasserman, N. 2008. The Founder's Dilemma. Harvard Business Review, 86(2): 102-109.

Welpe, I. M., Spörrle, M., Grichnik, D., Michl, T., \& Audretsch, D. B. 2012. Emotions and Opportunities: The Interplay of Opportunity Evaluation, Fear, Joy, and Anger as Antecedent of Entrepreneurial Exploitation. Entrepreneurship Theory and Practice, 36(1): 69-96.

Wiklund, J., Davidsson, P., \& Delmar, F. 2003. What Do They Think and Feel About Growth? An Expectancy-Value Approach to Small Business Managers' Attitudes toward Growth. Entrepreneurship Theory and Practice, 27(3): 247-270.

Woolley, A. W., Chabris, C. F., Pentland, A., Hashmi, N., \& Malone, T. W. 2010. Evidence for a Collective Intelligence Factor in the Performance of Human Groups. Science, 330(6004): 686-688.

Wu, S., Matthews, \& Dagher, G. K. 2007. Need for Achievement, Business Goals, and Entrepreneurial Persistence. Management Research News, 30(12): 928941.

\begin{abstract}
About the Author
Anna Brattström works at Lund University, Sweden. Her research focuses on how people come together and work together in contexts such as innovative start-ups or inter-organizational $\mathrm{R} \& \mathrm{D}$ alliances. Her work has been published in journals such as the Academy of Management Journal, Organization Studies, Research Policy, Entrepreneurship Theory and Practice and Journal of Product Innovation Management.
\end{abstract}

Citation: Brattström, A. 2019. Working with Startups? These are the Three Things You Ought to Know about Startup Teams.

Technology Innovation Management Review, 9(11): 5-14.

http://doi.org/10.22215/timreview/1279

(cc) BY

Keywords: entrepreneurship, new venture teams; teamwork 